\title{
NEW GEOMETRIDAE IN THE TRING MUSEUM FROM NEW GUINEA.
}

\author{
By W. WARREN, M.A., F.E.S. \\ SubFamily ORTHOSTIXINAE. \\ 1. Ozola violacea spec. nov.
}

Forewing: yellow ochreous, the ground colour almost entirely hidden by reddish and violet-brown suffusion; costal edge yellow dotted with black; the costal streak filled with dense reddish striae; inner line oblique ontwards from one-third of costa to middle of cell, blackish, thence nearly vertical or slightly curved inwards and illdefined to middle of inner margin, the basal area within it red, being almost covered with confluent vinous striae and suffusion ; outer line from two-thirds of costa, dark and sinuous, to inner margin a little beyond inner line, the excurved portion between costa and vein 2 filled up with deep red; the central area hyaline white with coarse red granular speckling and with a red triangle at top below subcostal vein ; subterminal line formed of black blotches between the veins, often indistinct; area beyond onter line vinous red-brown glossed with violet, containing a small yellow red-speckled patch on termen from vein 4 to 2 and a slighter patch at apex ; terminal dark dots between veins ; fringe reddish except beyond the yellow areas.

Hindwing: with the whole basal half yellowish hyaline with partially confluent red speckling; the outer half as in forewing, but without any yellow patches.

Underside similar to upper ; the outer lines blacker, distinctly crenulate.

Head, thorax, and abdomen red speckled with yellow, the dorsum more solidly red ; venter, pectus, and legs variegated red and yellow.

The $q$ is less strongly suffused with red, the pale ground colour being more in evidence.

Expanse of wings : $35 \mathrm{~mm}$.

A series from near Setekwa River, Snow Mts., Dutch New Guinea, up to $3500 \mathrm{ft}$., October and December 1910 (A. S. Meek).

\section{Subfamily GEOMETRINAE.}

2. Agathiopsis maculata angustifascia subsp. nov. and unanimis subsp. nov.

In Nov. Zool. iii. p. 286 I described this species from Fergusson Island; in it the $\delta$ differs from the $q$ in having the marginal dark border narrower and darker, with straighter inner margin, than in that sex ; of the four from the Solomon Islands (Bongainville), subsp. angustifascia has this border still narrower and more concise, the inner edge white; on the other hand, of four examples from Ninay Valley, Central Arfak Mts., Dutch New Guinea, subsp. unanimis, the $2 \delta \delta$ are only distingnishable from the $q q$ by the round green terminal blotch between veins 3 and 4 , the border in both sexes being of the same colonr and shape as in typical $q q$.

3. Anisogamia absona Warr. ab. exalbata nov.

Differs from the type in having all the white spaces exaggerated ; in the forewings the spots forming the outer line and the inner of the two submarginal lines 
conflnent into nneven bands, partly joined along submedian fold with a short inner band below the cell-spot; the outer bands broad also in the hindwings; the patagia white instead of green; the dark blotch at apex of hindwings hardly visible above, though equally strong below. 1 o from Ninay Valley, Central Arfak Mts., Dutch New Guinea, $3500 \mathrm{ft}$., November 1908 to January 1909, along with 8 typical $\delta \delta$ and 1 $q$. Both sexes are slightly different from the Australian fascinans of Lueas $=$ dentata $\&$ Warr. In the $\delta$ the hindtibiae are grooved, with an expansible pencil of long dark hairs concealed therein.

\section{Anisogamia albiguttata spec. nov.}

Forewing: white; the basal three-fourths traversed by numerous irregular green vermiculations thickened into blotches between veins 2 and 3 and in submedian interval; a brown subcostal spot at one-fonrth and a dark green spot at each end of discocellular ; the limit of basal area and the inner edge of central fascia can be imagined only ; the outer edge of the latter is marked by a lnuulate-dentate green line, followed by a dentate white band; terminal area dark green, containing two rows of white lnnules, separated by the green veins; those of the inner series more elongate ; marginal line deep green interrupted by large white dots at the vein ends; fringe green, with the tips grey-brown dotted with white beyond the veins ; costa with a few earth-brown speckles at base, thickened at middle, and confluent towards apex, which is brown with white dots.

Hindwing: similar, but the white spaces and the green striae larger and clearer, more regular.

Underside pearly white, the green markings of npperside showing by transparence only, except above median in forewing, where the discocellular, an onter, and subterminal line are marked in green below costa, the subterminal by four green lunules; the costal streak, the terminal lunules below apex and the fringe tips fawn-colour.

Head, thorax, and abdomen green powdered with white, the last with dorsal and subdorsal rows of white spots ; pectus, venter, and legs white ; forelegs tinged with fawn-colour; antennae with the shaft white and the short rigid pectinations dark fawn-colour.

Expanse of wings : $27 \mathrm{~mm}$.

$1 \delta$ from near Setekwa River, Snow Mts., Dutch New Guinea, up to $3500 \mathrm{ft}$.; October to December 1910 (A. S. Meek).

\section{Anisogamia fragmentata Warr. ab. major ab. nov.}

Like so many other New Guinea insects, this species occurs of two sizes; of $5 \delta \delta$ and $2 q q$ from Ninay Valley, Central Arfak Mts., Dutch New Guinea, $1 \delta$ only agrees in size with the type specimens from Biagi; the rest expand $36 \mathrm{~mm}$. and the $f$ \& $38 \mathrm{~mm}$. These examples-which may be separated as ab. majoragree exactly with the type, but the white markings are clearer and more distinct; the $q q$, as usual, are quite different. The pale costal streak is thickly dasted with fuscous atoms ; the outer line from two-thirds of costa to two-thirds of inner margin is white inwardly edged with lilac grey, more broadly above vein 6 ; between veins 6 and 5 the line forms a small sinus outwards and is abruptly broken off at vein 3 ; the terminal area beyond is greyish white, containing a green blotch beyond the sinus, below which the white line is ontwardly as well as inwardly edged with lilac grey; 
between veins 3 and 1 the grey termen is quite narrow, ending in a rounded white blotch at two-thirds of inner margin; veins across border dark; marginal lunules blackish ; fringe grey ; in the hindwing the terminal border is narrower at costa and very narrow before tornus; on middle of inner margin is a narrow grey streak expanding towards base.

\section{Anisogamia reducta spec. nov.}

ठ. Forewing: pale semitransparent green; the veins deep green with pale dots; costa deep brown dotted with white; basal area crossed by three or four interrupted pale lines, most distinct on inner margin ; at one-third an obscure cloudy pale curved band; two submarginal rows of pale spots between the veins, those on each side of vein 4 swollen; a row of pale dots close before termen; terminal line crenulate, dark green, with pale dots at the vein ends; fringe grey-green.

Hindwing: Similar, without the pale band; a brownish blotch at apex between veins 7 and 8 .

Underside iridescent pale green, with the white marks showing through; costa of forewing yellowish, with slight fuscous markings.

Head, thorax, and abdomen dark green, mixed with whitish scaling; lower part of face and ontside of palpi greenish white; dorsal segments of abdomen with white spots at their hinder edge; segments 5 and 6 dorsally dark fuscous.

. Forewing with the pale band ending in a brown spot on inner margin; termen dark greenish fuscons, its inner edge projecting roundly on vein 5 , and followed by a deeper shade; terminal line crenulate, blackish ; fringe fuscous, with pale dots at base between veins.

Hindwing: the same.

Underside with the terminal band whitish, edged inwardly by a narrow dark band indented in middle in both wings ; costa of forewing yellowish. Dorsum dark fuscons, mixed with a few greenish scales; anal tuft whitish.

Expanse of wings : $\delta 25 \mathrm{~mm}$; $\uparrow 25-28 \mathrm{~mm}$.

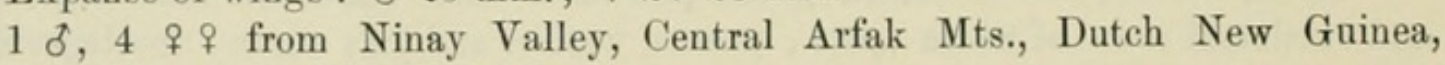
$3500 \mathrm{ft} .$, February and March 1909.

The $q$ resembles that of dentata Warr., but is smaller, and the dark border is withont any reddish tinge.

\section{Anisogamia semilineata spec. nov.}

Forewing : deep green, very slightly transparent; costa dark brown with white dots and a quadrate white spot at one-third; a white dot at base of each fold and a larger one beyond the lower one; a narrow white spot across each fold, hardly forming a line; inner line starting from the white costal spot forms a bracket-shaped white mark across cell, below middle marked by two white dots, on median vein and vein 1 , and two more, on submedian fold and inner margin ; onter line at four-fifths, lunulate-dentate, but very obscure, the teeth forming white dots on veins, and the lunules white dots between them, starting from vein 6 ; two submarginal rows of white spots, the inner somewhat elongated vertically, the outer horizontally; a fine dark green crenulate terminal line, with white dots at the vein ends; fringe pale green tipped with white.

Hindwing: with two white spots at base and a white cell-spot on npper half of discocellular, preceded by two large white spots in cell; three white spots below 
submedian fold, the first joined by a bar to median vein; a white spot at base of veins 2 and 3 ; onter line zigzag, white, interrupted in cell and marked by a white spot on vein 5 nearer base; the rest as in forewing.

Underside very pale whitish green, the white marks of upperside showing through; costa of forewing yellow, with a few brown specklings ; the outer line and inner of the two submarginal lines marked at costa by darker green and fuscous; three dark terminal dots below apex.

Head, thorax, and dorsum dark green; lower part of face white; palpi pale pinkish brown; three rows of white dorsal spots on abdomen; the middle row on the hinder edge of the segments, the lateral rows on their middle; pectus, venter, and legs white; the forelegs in front dark brown, with the joints white.

Expanse of wings : $26 \mathrm{~mm}$.

$1 \delta$ from the Ninay Valley, Central Arfak Mts., Dutch New Guinea, $3500 \mathrm{ft}$., November 1908 to Jannary 1909.

\section{Anisogamia veniplaga Warr.}

In Nov. Zool. xiv. p. 130 (1907), the $\delta$ only of this species was available for description: I am now able to add that of the $q$, which differs considerably. The costal streak is broader, white densely freckled with brown, without any reddish tint; instead of the two terminal blotches at apex and tornus, both wings have a broad bone-coloured terminal border, edged inwardly by a white line consisting of large lunules, starting from two-thirds of costa and ending at three-fourths of inner margin, twice as broad above vein 4 as below it, the line being dentate ontwards at veins $6,4,3$, and 2 ; towards apex of forewing the border is faintly tinged with fleshcolonr, and is traversed by a darker clond beyond the white limiting line, increasing in depth below middle of forewing and much more developed throughout the hindwing, without any reddish tint; the veins across the pale border are dotted with dark, and the marginal lunules black; the fringe bone-colour, varied with grey ; below the costa of forewing on each side of vein 7 is an elongated patch of green. On the underside of forewing the black spot at anal angle is replaced by a broad black shade reaching costa, running in the main along the inner edge of the pale outer border.

Expanse of wings : $39 \mathrm{~mm}$.

$1 \subsetneq$ from Ninay Valley, Central Arfak Mts., Dutch New Guinea, $3500 \mathrm{ft}$., February and March 1909, along with $2 \delta \delta$ from the same locality, somewhat smaller than the type $\delta-32 \mathrm{~mm}$. instead of $37 \mathrm{~mm}$.

\section{Anisogamia viridistriga spec. nov.}

Forewing: whitish, above the middle suffused in parts with green and traversed by many thick wavy dark green lines, all plainest below middle; the basal and subbasal starting from blackish costal spots, and developing into waved green lines below subcostal vein ; the edges of the central fascia dark green, starting from black spots on costa, the inner curved from costa, then vertical, preceded by a distinct pale band of ground colour; the outer strongly dentate on veins, the two edges twice as near each other on inner margin as on costa, containing two somewhat interrupted dark green lines between them below middle and two more in onter half of cell; the pale band following the fascia not so plain as that preceding it; a pale green patch at apex, becoming a narrow green band below middle, the upper part to vein 6 
traversed by three white lunules representing the subterminal line; a row of broad green lunnles along termen, preceded, except beyond cell, by larger white lunules, separated by the green veins; fringe pale green; costa between the black spots white, at middle and beyond marked with black dots.

Hindwing: with the terminal area as in forewing; the rest of the wing crossed by numerous waved and partially interrupted pale and dark green striae, the pale ground colour slightly discoloured with pinkish ochreous.

Underside of forewing greenish white, crossed by three reddish and dark fuscons bands, the inner slight, the middle and onter forked and swollen above median and forming thick dentate lines below ; costa dotted with dark; hindwing with two black fasciae, the median broad at costa, thinning out to inner margin, the outer submarginal projecting inwards at middle; both with their outer edges dentate; marginal lunules black; fringe of both wings pale green.

Face deep green, white below ; shoulders, patagia, and base of dorsum green, the patagia whitish at base; abdomen (discolonred); palpi pale brown ; vertex broadly white, with a dark green line behind.

Expanse of wings : $30 \mathrm{~mm}$.

A fair series from near the Setekwa River, Snow Mts., Dutch New Guinea, up to $3500 \mathrm{ft}$., October to December 1910 (A. S. Meek).

\section{Genus Blechromopsis gen. nov.}

Snperficially much resembling the S. American genus Blechroma Moeschl., from which it is distinguished by its somewhat thicker scaling, and the longer and less regular pectinations of the antennae of the $\delta$; the palpi obliqnely porrect upwards, the terminal segment longer in $q$; hindwing with a slight tooth at vein 4 ; veins 6, 7 hardly stalked; the lines accompanied by brown scaling, as in Anisogamia muscosa Warr., which has the termen of both wings strongly crenulate.

Type B. nubifera spec. nov.

The species described by me as Agathia punctata (Nov. Zool. vi. p. 327, 1899) from Dammer Island will come into this genus.

\section{Blechromopsis costipicta spec. nov.}

Forewing: grass-green; the costa bright pale ochreous with dense short chocolate-brown dots; a small brown spot at base of cell, and a slighter one on subcostal, representing the subbasal line; iuner line chocolate brown, deeply lunulate-dentate, the inward teeth marked with brown spots on the veins, the lunules filled in with pink; a thick brown bar across discocellular, followed by a few brown striae ; outer line deeply lunulate-dentate, the lunules partly interrupted, the teeth marked by brown dots, preceded below middle by pale dashes ; fringe green ; no terminal spots or mottling of fringe.

Hindwing: with inner line waved, violet brown ; cell-spot minute ; outer line deeply lunulate-dentate, only the teeth marked reddish, preceded by pale dashes, the lunule between 4 and 5 pinkish; both lines ending in stronger brown spots on inner margin; a minute dark dot in the tooth at vein 4 ; fringe green.

Underside whitish green; costa of forewing yellow with numerous strong brown striae; below it the costal half of wing is deeper green.

Face ochreous, becoming violet brown above; palpi dark brown externally, ochreous internally ; fillet brown; antennal shaft ochreous mottled with brown; 
vertex, thorax, and dorsum green, the last with white segmental spots; underside and legs white, the forelegs fuscous in front.

Expanse of wings : $32 \mathrm{~mm}$.

1 o from near the Oetakwa River, Snow Mts., Dutch New Guinea, up to $3500 \mathrm{ft}$., October to December 1910 (A. S. Meek).

The forewings are narrow, as in B. megaspila fiom the same locality.

\section{Blechromopsis dissimilis spec. nov.}

Resembles B. costipicta, but deeper green ; the costa green with short brown striae; the lines the same, but more violet; the lunnles of the inner line filled in with whitish; the cell-spot a small dark spot; hindwing as in costipicta, with no dot in the tooth at vein 4 .

Underside with the costal edge very shortly striated to just beyond middle.

Face green instead of ochreous.

Expanse of wings : $34 \mathrm{~mm}$.

1 ठ from Upper Setekwa River, Snow Mts., Dutch New Gninea, 2000 to 3000 ft., August 1910 (A. S. Meek).

The wings are mnch broader, the termen of forewing nearly straight, and the anal angle well marked, agreeing herein with $B$. nubifer $a$.

\section{Blechromopsis nubifera spec. nov.}

Forewing: grass green; the costa yellow, with numerous chocolate brown striae; a brown spot at base of cell ; some brown striae on subcostal vein represent the subbasal line ; inner line from one-fourth of costa to one-third of inner margin, starting from a brown costal spot, lunulate-dentate, the teeth on the veins long and pointing inwards, the Junules, which are deep, outwards; brown inwardly whitishedged, the lunules preceded by grey-brown shading, the semi-lunule below vein 1 faint and pinkish ; cell-spot black, lying in a clond of grey-brown striae; outer line from three-fourths of costa to two-thirds of inner margin, strongly lunulate-dentate, the white teeth on the veins tipped with green below vein 4 and with brown above it, the lunules thickly brown from costa to vein 5 , that between 4 and 5 pink-tinged; the teeth on veins $8,7,6$ brown and confluent; minute brown dots at the vein ends followed by pink spots across the green fringe.

Hindwing: inner line marked by pink spots on each fold; cell-spot pink; onter line strongly lunulate-dentate, the teeth white tipped with dark green, the lunnle between 4 and 5 marked with pink; brown terminal spot in the tooth at vein 4 large ; an elongate narrow brown blotch at anal angle, below a pink spot on inner margin at end of outer line.

Underside pale green ; the costal half of forewing bright green; the costal edge yellow with short brown striae; the fringes spotted with pink beyond the dark terminal dots.

Palpi externally, face, vertex, thorax, and dorsum deep green ; fillet dark brown; antennal shaft ochreous dotted with brown, the pectinations in the $\delta$ mottled brown and ochreous ; dorsum with white segmental dots in the $\delta$; underside and legs white, the forelegs tinged in front with fuscous brown.

Expanse of wings : $\delta 42 \mathrm{~mm}$.; $\uparrow 44 \mathrm{~mm}$.

The type $\delta$ from the Upper Setekwa River, Snow Mts., Dutch New Guinea, 2000 to $3000 \mathrm{ft}$., August 1910, the $q$ from near the Oetakwa River, up to $3500 \mathrm{ft}$., October to December 1910 (A. S. Meek). 
13. Blechromopsis megaspila spec. nov.

Forewing: bluer green than in nubifera ; the costal edge green striated with brown; a large brown spot at base of costa ; a small one on costa and subcostal vein, indicating subbasal liue ; inner line as in nubifera, but forming a brown blotch from costa to median vein, then interrapted, the teeth marked brown on the veins, and the tip of the upper lnuule and that on inner margin brown; a brown cell-spot and a spot above it at rise of vein 6 ; onter line strongly lunulate-dentate, the lunules marked with brown and edged with white, the teeth forming dark brown spots, the lunules sometimes faint; the upper part of line to vein 6 forming an elongate brown blotch between 6 and 7 , and the teeth another between 7 and 8 ; terminal dark brown spots large, those on veins 1 and 4 forming round blotches; the fringe green chequered with pink beyond veins.

Hindwing: with inner line faint, green ; cell-spot red-brown ; teeth of onter line marked by small brown dots; the lunnles unmarked exçept sometimes on each fold; a brown pink-tinged spot on inner margin at end of the line; the spots at end of veins 1 and 4 large as in forewing, that at vein 7 elongate.

Underside pale green; the costal edge of forewing yellowish, dotted with brown ; traces of the brown markings of upperside below costa only.

Face, vertex, thorax, and abdomen deep green; palpi externally brown, internally whitish ; fillet brown; antennal shaft ochreous, dotted with brown, the pectinations mottled in the $\delta$; base of patagia with a large brown spot; basal segments of dorsum with large brown spots; venter, pectus, and legs white; the forelegs fuscons brown in front.

Expanse of wings : o $38 \mathrm{~mm}$.; $q 43 \mathrm{~mm}$.

Several specimens from near the Oetakwa River, Snow Mts., Dutch New Guinea, np to $3500 \mathrm{ft}$., October to December 1910 (A. S. Meek).

The markings appear to be stronger in the $q$.

\section{Chlorochroma angulilinea spec. nov.}

Forewing: bright deep green; the terminal intervals marked with rows of yellow dots conflnent into streaks; costa deep yellow, underlined with deep red scales; the lines yellow ; the inuer strongly angled outwards on median vein at the rise of vein 2 ; the outer oblique and straight from two-thirds of inner margin to four-fifths of costa; a subbasal line oblique from base of inner margin to median vein; a yellow line on discocellnlar; fringe yellow beyond a fine red terminal line.

Hindwing: with inner line straight from below costa near base to one-third of inner margin ; outer line from two-thirds of costa to two-thirds of inner margin ; strongly but bluntly angled ontwards below vein 4 ; the line on discocellular sickleshaped; terminal red line thick; yellow streaks between veins towards termen as in forewing.

Underside pale green, with the pale lines showing through ; costa of forewing yellow.

Face, thorax, and abdomen deep green; a yellow dorsal streak starting from thorax ; palpi green above, white below ; fillet and antennal shaft yellow ; pectus and venter white; legs tinged with green.

Expanse of wings : $37 \mathrm{~mm}$.

1 o from near Setekwa River, Snow Mts., Dutch New Guinea, up to $3500 \mathrm{ft}$., October to December 1910 (A. S. Meek).

Forewings narrower with apex more prominent. 


\section{Chlorochroma bicornuta spec. nev.}

Forewing: bright apple green ; costal edge white, underlined with red, most strongly before apex, and wholly red at extreme base; lines paler, faintly crenulate; the inner oblique from one-fifth of costa to one-third of inner margin ; the outer at two-thirds, oblique ontwards to vein 6 , there bluntly angled and oblique inwards parallel to termen, slightly onteurved above inner margin; the inner line is followed, as the outer is preceded, by slightly darker green, towards costa faintly red-tinged ; discocellular grey-brown, marked with a deeper spot at top and at the angle below, emitting a grey-brown tooth along vein 5 parallel to that on lower arm; terminal line deep red, marked with red points at end of veins, slightly swollen at vein 1 ; fringe yellow.

Hindwing: with large black-brown cell-spot and curved onter line; the terminal lines and spots thicker.

Underside whitish, deep green below the white costa of forewing, which is tinged with red at base and underlined with dark towards apex; discocellular obscnrely marked with fawn-colour; dark terminal dots on forewing from apex to vein 4 .

Face, thorax, and dorsum green, the last with a broad yellow stripe; palpi white beneath, reddish above, with the tips red-brown; vertex and shaft of antennae snow-white ; occipnt deep red; pectns, venter, and legs white; forelegs tinged in front with dull red.

Expanse of wings : $30-32 \mathrm{~mm}$.

$2 \delta \delta$ from the Setekwa River and the Oetakwa River respectively, Snow Mts., Dutch New Guinea, up to $3500 \mathrm{ft}$., October to December 1910 (A. S. Meek).

The discocellular mark of forewing is shaped as in rufimargo.

\section{Chlorochroma consobrina spec. nov.}

Extremely like C. rufistriga Warr. (Nov. Zool. xiii. p. 85 (1906)), but distinguished by the inner line, which is curved, not straight; cell-mark a dark spot, not a linear mark; the hindwing has the hindmargin bluntly but distinctly angled at middle, instead of being rounded.

Expanse of wings : $38 \mathrm{~mm}$.

$2 \delta \delta, 2$ $q$ from Ninay Valley, Central Arfak Mts., Dutch New Guinea, $3500 \mathrm{ft}$., November 1908 to March 1909.

\section{Chlorochroma delicata spec. nov.}

Forewing: bright green, thickly scaled; costa narrowly yellow, with the extreme base green; lines very indistinct, marked by white points on the veins ; the onter line nearly straight, not incurved below middle, as in C. strigicosta; fringe shining yellow, with the terminal dots minute; cell-spot green.

Hindwing: with outer line only, bent at middle.

Underside paler green, with the terminal dots plainer; costa of forewing yellow finely speckled with fawn-colour; the subcostal area deeper green.

Face, ontside of palpi, vertex, thorax, and dorsum green ; fillet and shaft of antenuae snow-white ; pectus, venter, and legs white.

The hindwing has the termen less strongly bent at vein 4 than in C.strigicosta.

Expanse of wings : $38 \mathrm{~mm}$.

$1 \delta, 1$ from near Oetakwa River, Snow Mts., Dutch New Guinea, up to $3500 \mathrm{ft}$., October to December 1910 (A. S. Meek). 
18. Chlorochroma indentilinea spec. nov.

Forewing: apple green, extremely finely irrorated with minute pale atoms; costal edge ochreous white, underlined with lilac grey; the lines whitish, the inner excurved from subcostal vein at one-fifth to one-third of inner margin ; the onter lunulate-dentate from below costa at two-thirds, ontcurved above middle, and strongly incurved from vein 3 to submedian fold, thence vertical ; cell-spot lunular, brown, with a deeper brown spot at lower end ; terminal line lilac, darker at the vein ends ; fringe yellow.

Hindwing: with the inner line waved, nearer base; the outer line with a prominent projection between veins 3 and 4 , thence strongly inbent; cell-spot with the dark spot at lower end more prominent; fringe and terminal line as in forewing.

Underside pale green; a triangular space from costa of forewing deeper green.

Face, collar, thorax, and abdomen green, the last with a broad yellow dorsal stripe starting from middle of thorax; palpi green above, white below ; vertex snowwhite, with a bright red band behind it; antennal shaft white, the pectinations green; pectus, legs, and venter white.

Expanse of wings : $42 \mathrm{~mm}$.

$1 \delta$ from near Setekwa River, Snow Mts., Dutch New Guinea, up to $3500 \mathrm{ft}$., October to December 1910 (A. S. Meek).

\section{Chlorochroma pomonae spec. nov.}

Forewing: delicate pale green ; costal edge speckled white and pale fuscous; lines marked by very faint darker green shades with lnnulate-dentate edges, the white teeth on the veins alone conspicnons; a dark green cell-spot; fringe yellow.

Hindwing: with dark green cell-spot and the onter line more bent in middle.

Underside pale green ; costal edge of forewing fuscous-speckled.

Head, thorax, and dorsum green ; fillet and antennal shaft, pectus, venter, and legs white; palpi externally green.

Expanse of wings : $40 \mathrm{~mm}$.

$1 \subsetneq$ from Ninay Valley, Central Arfak Mts., Dutch New Guinea, $3500 \mathrm{ft}$.. Febrnary and March 1909 (A. S. Meek).

\section{Chlorochroma rufimargo spec. nov.}

Forewing: apple green; costa deep pink, the costal edge, except at base and before apex, narrowly white; lines diffusely paler green ; the inner oblique from onefourth of costa to one-third of inner margin, outwardly dentate on median vein and slightly on vein 1, followed by a darker shade of green; outer line oblique outwards to vein 6 , then curved and parallel to termen to two-thirds of inner margin, obscurely dentate-lunulate and slightly swolleu on the veins, preceded by a darker green shade; terminal line thick, pink, swollen along the veins to form triangles, with a faint yellow edging, marked with a dark dot from apex to 6 ; fringe yellow ; cell-mark angular, red-brown, with a projection from its upper end, parallel to the lower arm.

Hindwing: with the cell-spot round, bright red ; the outer line well curved.

Underside very pale green; costa of forewing pale; some obscure reddish grey scaling along upper edge of cell, over the cell-mark, and above veins 6 and 7 at their base; fringe yellow, with black dots at base from vein 4 to apex. 
Face, thorax, and sides of abdomen green ; vertex snow-white with a bright red line behind; palpi red above, white below; a broad pink dorsal line swollen into triangles on each segment; the anal tuft white; pectus, venter, and legs white; forelegs red in front.

Expanse of wings : $32 \mathrm{~mm}$.

$2 \delta \delta$ from near Oetakwa River, Snow Mts., Dutch New Guinea, up to $3500 \mathrm{ft}$., October to December 1910 (A. S. Meek).

\section{Chlorochroma rufinotata spec. nov.}

This species very closely resembles C. laticostata Warr., Nov. Zool. xiii. p. 84 (1906), described from the Angabunga River, British New Guinea, but differs as follows : it is rather larger in point of size, expanding $32 \mathrm{~mm}$. against $26 \mathrm{~mm}$; the two lines are darker green, slightly red-tinged, especially at the teeth on the veins, and are not marked with white points; both lines of the forewing and the outer in the hindwing end in red spots on inner margin ; the fringes are strongly tinged with red, instead of being pure yellow.

Two $\delta \delta$ from near the Oetakwa River, Snow Mts., Dutch New Guinea, up to $3500 \mathrm{ft}$., October to December 1910 (A. S. Meek).

\section{Chlorochroma serratilinea spec. nov.}

Closely allied to $C$. indistincta Warr., Noo. Zool. x. p. 355 (1903), from the Upper Aroa River, British New Gninea, but the lines are white and distinct, very strongly dentate ; the white costa is underlined with fawn-colour; lastly, the fringes are grey, not green, much darker on the underside and dotted with dark beyond veins; the underside of both wings whitish throughout; dorsum with white spots on last four segments.

Expanse of wings : $34-36 \mathrm{~mm}$.

Two $q$ from near the Oetakwa River, Snow Mts., Dutch New Guinea, up to $3500 \mathrm{ft}$., October to December 1910 (A. S. Meek).

\section{Chlorochroma strigicosta spec. nov.}

Forewing: pale green, somewhat thinly scaled and semitransparent; costa green at extreme base, then white densely striated with fawn-colour; lines pale, very indistinct; inner oblique outwards from near base of costa to one-third of inner margin, dentate inwards on veins, the teeth marked by. pale points; onter line lunulate-dentate, at two-thirds, the teeth marked by white vein-points, preceded by a darker shade of green ; cell-spot red-brown, lunulate; fringe yellow, with minute dark points at ends of veins.

Hindwing: with outer line only, excurved in middle ; cell-spot linear, green.

Underside paler green; costa of forewing yellowish freckled with brown; the subcostal area deeper grcen.

Face, vertex, thorax, and abdomen green ; palpi green externally, white within ; fillet snow-white ; pectus, venter, and legs whitish.

Expanse of wings : $40 \mathrm{~mm}$.

One $q$ from near Oetakwa River, Snow Mts., Dutch New Guinea, up to $3500 \mathrm{ft}$., October to December 1910 (A. S. Meek).

Allied to $C$. marginepunctata Warr., but that species has the costa wholly white. 
24. Chrysochloroma rubritincta Warr., ab. fuscimargo nov.

In Nov. Zool. vol. iii. p. 364 (1896) I described rubritincta from New Guinea as a subspecies of (subalbida Warr.) = megaloptera Lower from North Queensland. Having now seen several specimens of both forms, I am convinced that rubritincta is a good species. Of two $q$ from the Oetakwa River, Snow Mts., Dutch New Guinea, one agrees perfectly with the type, the other I describe as ab. fuscimargo nov.; in it the forewing has a clondy fuscous marginal shade from anal angle becoming obsolete above middle, while the hindwing possesses a broad fuscous terminal clond, which fades out before the anal angle; the large cell-spot of hindwing is encircled by a diffuse fuscous clond, and there are two or three small patches of fuscous scales between it and the terminal border; in all other points it agrees with typical specimens. The two examples were taken by A. S. Meek between October and December 1910.

\section{Dioscore simplex spec. nov.}

Forewing: dull grey-green; inner line marked by white dots on the veins; onter line by a curved row of white vein-spots at two-thirds; fringe dark grey, with large white spots beyond the veins.

Hindwing: with the row of spots ronndly bent at middle; a shining white slightly raised spot on upper arm of discocellular.

Underside much paler, somewhat yellowish-tinged towards costa.

Face, tips of palpi, and forelegs pale brown; vertex, thorax, and dorsnm concolorous with wings; fillet and antennal shaft white.

Expanse of wings : $46 \mathrm{~mm}$.

2 \& from Ninay Valley, Central Arfak Mts., Dutch New Guinea, 3500 ft., February and March 1909.

\section{Gelasma saturata spec. nov.}

Forewing: very deep grass-green; lines faintly paler, but very indistinct; the inner curved and followed by a slightly darker shade; the outer from threefourths of inner margin, nearly parallel to termen, and becoming obsolete above middle; a small brown cell-spot; a fine brown terminal line slightly swollen between veins; fringe brown, rather glossy, with the base somewhat paler.

Hindwing: with a large brown cell-spot; the outer line plainer and bent below middle; the terminal area broadly brown; fringe as in forewing.

Underside brighter green; fringe of both wings dark brown; termen of hindwing with some small dull brown clonds between the veins.

Vertex, thorax, and abdomen concolorous with wings; face deep brown above, paler below ; palpi above deep brown, below greenish white; antennae deep green; pectus and venter whitish green.

Expanse of wings : $42 \mathrm{~mm}$.

1 of from the Upper Setekwa River, Snow Mts., Dutch New Guinea, 20003000 ft., Jnly 1910 (A. S. Meek).

Allied to G. electrica Warr., Nov. Zool. iii. p. 363 (1896), from Ron Island, New Guinea.

\section{Halterophora nereis spec. nov.}

Forewing: deep sea-green, marked with three oblique white bands; the first broad near base, from inner margin to upper edge of cell, slightly waved, and 
pointed at top, followed by a faint pale line before the dark green cell-spot; outer band white, its edges slightly lunulate-dentate from costa before apex, where it is thin and faint, to middle of inner margin, more oblique inwards below vein 4 ; a less distinct snbmarginal band, oblique below vein 2, ending near outer band; slightly paler green horizontal streaks in the intervals above vein 4 before onter line; a fine dark green marginal line; fringe green; costa minutely brownspeckled.

Hindwing: with base dark green, followed by an inner white band, on the edge of which is the deeper green cell-spot; a broad curved white band from before apex to two-thirds of inner margin, with diffuse outer edge, and a submarginal one from apex to tornus.

Underside whitish green, the pale bands showing through; costal area, and cell-fold of forewing, and base of hindwing deep green.

Head and thorax deep green; abdomen paler green, with white segmental belts; antennae green.

Expanse of wings : $44 \mathrm{~mm}$.

1 o from Ninay Valley, Central Arfak Mts., Dutch New Guinea, 3500 ft., November 1908 to January 1909.

Allied to but distinct from thalassias Warr.

\section{Mixochlora radiata spec. nov.}

Forewing: deep green, with paler lustrons green shading; an ontwardly oblique pale band from about one-fourth of costa to one-third of inner margin ; an oblique slightly curved pale line from below three-fourths of costa to middle of inner margin, emitting pale horizontal streaks ontwards between the veins, diminishing in lengti and clearness npwards; another pale line, more strongly curved, from apex to inner margin before anal angle; the cell before and a slight space beyond the dark discal mark paler ; fringe green, with paler tips.

Hindwing: with a straight pale line in middle, emitting, as in forewing, pale rays outwards; a pale interrupted submarginal line; base of wing with paler streaks between the veins; the discal spot dark green.

Underside pale yellow-green, with dark green cell-spots, distinct onter, and slight submarginal lines; fringe dark green ; costa of forewing yellow.

Head, thorax, and abdomen deep green; centre of vertex whitish; the dorsum mixed with whitish.

Expanse of wings: of $46 \mathrm{~mm}$.; $q 48 \mathrm{~mm}$.

$3 \delta \delta, 1 \&$ from Ninay Valley, Central Arfak Mts., Dutch New Guinea, $3500 \mathrm{ft}$., February and March 1909.

\section{Genus 0xypora gen. nov.}

Wings thinly scaled, semi-transparent; costa straight but strongly shouldered at base; apex blunt; termen curved; the hindwing with a slight elbow at vein 4 ; palpi porrect, slender; tongue well developed; antennae of $\delta$ plumose to beyond middle; of $q$ with the segments triangular, closely pubescent; discocellular of forewing with the upper arm oblique inwards, then acutely angled inwards, the lower arm long and curved; of hindwing with the upper arm vertical to below the origin of vein 5 , then long and curved as in forewing; veins $6,7,8,9,10$ stalked 
from end of cell in forewing; 11 free, closely appressed to 12 but not anastomosing; in hindwing veins 6,7 stalked and (in one species) 3,4 also shortly stalked.

Type: Oxypora dentilinea spec. nov.

\section{Oxypora dentilinea spec. nov.}

Forewing : $q$ dull green, semitransparent; costal edge yellow with very fine dark strigae; lines shining whitish ; the inner at one-third much waved, indented on the veins and with a strong projection, faintly double, on each fold ; it is preceded by basal and snbbasal fainter lines parallel to it; outer line lunulate-dentate, strongly inbent at the folds; subterminal line parallel, but marked chiefly by the teeth on the veins and a single lunule across submedian fold ; veins towards termen finely dark green; terminal line fine, dark green, with whitish dots at the vein ends; fringe green.

Hindwing: withont basal lines; the short upper arm of discocellular marked by a shining whitish spot; a shining pale spot at base of both wings.

Underside pale green, with the markings showing through. In the of only the outer line is visible, the scaling being thicker.

Face and fillet greenish white; vertex, thorax, and basal half of dorsum green; anal half ochreous; legs and venter whitish; shaft of antennae whitish, the pectinations dark.

Expanse of wings : $\sigma^{\circ} 28 \mathrm{~mm}$., $\subsetneq 32 \mathrm{~mm}$.

A pair from the Upper Setekwa River, Snow Mts., Dutch New Guinea, 2000 to $3000 \mathrm{ft}$., August 1910 (A. S. Meek).

\section{0xypora spilota spec. nov.}

Forewing: dull green with the veins darker; costal edge strongly speckled with brown ; inner line waved as in dentilinea, but whiter, touching the dark green upper arm of discocellular; onter line marked by white spots on the veins; terminal line thicker ; fringe pale green with white dots at base between the veins.

Hindwing: with onter line only; upper arm of discocellular greenish white; a large white spot in tooth below vein 4 .

Underside pale green, with the white spots showing through.

Face greenish white; vertex, thorax, and dorsum green, segments 4 and 5 with black saddle-shaped blotches; underside and legs white; shaft of antennae pink, the pectinations pale.

Expanse of wings : $\delta$ o $30 \mathrm{~mm}$.

A pair from the Oetakwa River, Snow Mts., Dutch New Guinea, up to $3500 \mathrm{ft}$., October to December 1910 (A. S. Meek).

In this species the angle of discocellular in forewing is not so deep as in the type species; veins 6,7 are more shortly stalked in hindwing, while 3 and 4 are shortly stalked in hindwing and connate in forewing; in dentilinea vein 3 rises well before 4 .

\section{Probolosceles agathia spec. nov.}

Forewing: green; the costal edge yellowish; the markings reddish; lines donble, band-like, their edges deep red, the centre grey; first close to base, interrupted in middle, consisting of a subcostal spot and a smaller one on inner margin; second line just beyond middle, vertical, the edges lunulate between the 
veins; at vein 2 , where it joins the outer border, strongly curved inwards to near middle of inner margin; outer border broader, forming a slight sinus outwards between 4 and 6 and another from 4 to 2 , expanding below vein 2 into a rounded blotch; red terminal spots between veins; fringe reddish green.

Hindwing: with only the red border, which is broad at apex, redder-edged internally, forming a sinus outwards between 2 and 4 and a smaller one above, and a rounded blotch at anal angle, the inner margin narrowly red in middle.

Underside whitish green, the markings slightly indicated.

Face and palpi red above, white beneath ; fillet whitish, antennal shaft whitish, the pectinations reddish; shoulders bright green; patagia green with the tips reddish; dorsum red; pectus, venter, and anal segment pale greenish.

Expanse of wings : $20 \mathrm{~mm}$.

$1 \uparrow$ from Kumasi River, British New Guinea, August 1907 (A. S. Meek). The $q$ has pectinated antennae.

The markings recall those of the genus Agathia.

\section{Probolosceles moniliata spec, nov.}

Forewing: deep bright green; costa broadly cream-white, underlined with bright pink before apex; inner and onter lines marked by red spots on inner margin; the outer lunulate-dentate, but hardly traceable except by a deeper shade ; the terminal line deep pink, interrupted by large white spots at the end of the veins; fringe bright pink in basal half, whitish in apical ; cell-spots red-brown.

Hindwing: green, blurred with whitish and grey-green, deeper along costa ; traces of a crenulate onter line, ending in a red spot on inner margin; cell-spot red; fringe as in forewing.

Underside pale green, the forewing flushed with reddish towards base ; costa yellow ; fringe rosy.

Face, palpi externally, vertex, thorax, and dorsum deep green, the last paler towards anus ; fillet white ; pectus, venter, and legs whitish.

Expanse of wings: $26 \mathrm{~mm}$.

$1 \delta$ from Rendova, Solomon Islands, February 1904 (A. S. Meek).

Remarkable for the blurred green hindwings and bright pink fringes.

\section{Pyrrhaspis reversa spec. nov.}

Forewing: dull green with scattered pale vermiculations; costal edge white, becoming ochreous towards apex; lines marked by white dashes on veins; the inner very inconspicnons, oblique ontwards; the onter as in glauca nearly straight, commencing at vein 6 , the dash on vein 3 slightly exterior to the rest, that on vein 1 the same size as the others; upper arm of discocellular green, the lower curved part silvery white; large white terminal spots at the ends of the veins running out into the fuscous fringe.

Hindwing: without inner line; the outer bent on vein 4; the upper part of discocellular silvery white, the lower green ; terminal spots and fringe the same as in forewing.

Underside uniform whitish green.

Face, palpi, thorax, and abdomen green, the last with white segmental rings and dorsal spots; vertex, pectus, venter, and legs whitish; forelegs reddish in front. 
Expanse of wings : $46 \mathrm{~mm}$.

1 from Upper Setekwa River, Snow Mts., Dutch New Guinea, up to $3500 \mathrm{ft}$., October to December 1910 (A. S. Meek).

\section{Thalassodes flavifimbria spec. nov.}

Forewing: rather deep green, the scaling thicker than in veraria Guen., with a few whitish strigulae; the costal edge pale yellow ; inner line fine, white, oblique to one-third of inner margin; onter straight, white, at two-thirds ; fringe yellow.

Hindwing: with outer line running parallel to termen throughont, the lower part crenulate and finer; fringe yellow.

Underside paler green, the white outer line showing through ; costa of forewing yellow.

Face, thorax, and dorsum green; fillet and anal segment whitish.

Expanse of wings : $31-35 \mathrm{~mm}$.

2 ठิ $\delta$ from Kumasi River, British New Gninea, June 1907 (Meek).

The species resembles T. albifimbria from Sonth Africa, but the fringe is yellow instead of white and the face green; the termen of forewing is slightly bent at vein 4 .

\section{Thalassodes halioscia spec. nov.}

Forewing: deep sea-green, semihyaline and iridescent, with numerons pale vermiculations, which are slightly less abundant in the central area and make it appear darker; costa narrowly yellow; lines whitish, faint; the inner oblique at one-fourth, the green just beyond it deeper; the onter somewhat lunnlate-dentate at two-thirds, preceded by a deeper green shade and obsolete above middle; a deeper green cell-spot; fringe green.

Hindwing: with the outer line bent at vein 4.

Underside paler, with the costa of forewing yellowish.

Thorax and dorsum deep green ; tillet and antennal shaft white; face and palpi externally reddish brown; pectus, venter, and legs whitish ; the forelegs reddish in front.

Expanse of wings : $40 \mathrm{~mm}$.

1 o, 1 from Arawa, Bougainville, Solomon Islands, December 1907 (Meek). Broader-winged and deeper green than byrsopis Meyr.

\section{Thalassodes rubellifrons spec. nov.}

Exactly like 1. subviridis Warr., Nov. Zool. xii. p. 10 (1905), from Christmas Island, but the face and palpi are red instead of green.

$1 \delta$ from Ninay Valley, Central Arfak Mts., Dutch New Guinea, 3500 ft., November 1908 to January 1909.

\section{Subfamily DEILINIINAE.}

Genus Meekia gen. nov.

Forewing: elongate triangular; the costa straight ; apex prominent, blunt; termen obliquely curved; hindwing with termen and both angles rounded; scaling smooth and slightly glossy; base of hindwing shouldered, occupied in the $\delta$ by a swollen bladdery pustule; frenulum present, fine; tongue present; palpi 
porrect, decumbent, laterally flattened, the segments obscured; antennae lamellate, with short clavate teeth; legs simple, hind-tibiae with four spurs; neuration: forewing with cell a little longer than half of wing; discocellular vertical ; vein 2 at two-thirds, 3 close before 4 ; radials normal; $7,8,9$ stalked from before end of cell ; 10, 11 stalked, the stalk anastomosing at a point with 12, then again strongly with the stalk of $7,8,9$; hindwing with costal and subcostal shortly anastomosing at middle of cell; 3 and 7 well before angles of cell; no radial.

Type : Meekia flavicosta spec. nov.

This genus presents several anomalies.

37. Meekia flavicosta spec. nov. and ab. tincta nov.

Forewing: shining white, speckled with olive brown; costal streak brownish yellow with dark freckling; inner and outer lines at one-third and two-thirds, oblique parallel to termen, formed of brown specks, plain only in lower half of wing and not reaching the costa, in the $\delta$ hardly marked, except by brown spots on inner margin; slight brown terminal spots, stronger in $q$; fringe white ; cell-spot ronnd and black, distinct in $\$$, obsolete in $\delta$.

Hindwing: with the two lines distinct in lower half of wing in the $q$, absent in the $\delta$; cell-spot present in $q$ only.

Underside white : costa of forewing yellow ; terminal black dots present ; cellspots present in $q$ only.

Face and palpi brownish yellow ; vertex, thorax, and abdomen white; pectus, venter, and legs white; the forelegs brownish yellow in front.

Expanse of wings : $22 \mathrm{~mm}$.

$1 \uparrow, 2 \delta \delta$, from near Oetakwa River, Snow Mts., Dutch New Guinea, up to $3500 \mathrm{ft}$., October to December 1910 (A. S. Meek), and 1 of from the Upper Setekwa River, Angust 1910.

$2 \delta \delta$ from the former locality must be separated as ab. tincta; both wings, above and below, are pale straw-colour, except at base, which is white, like the vertex and thorax, while the abdomen is straw-colour; unlike the typical $\delta \delta$ these have the two lines, the cell-spots, and terminal dots as strongly marked as in the $q$. 


\section{NOTE ON CONURUS AERUGINOSUS AND THE ALLIED SPECIES.}

\section{BY T. SALVADORI, C.M.Z.S.}

$\mathrm{R}^{\mathrm{H}}$ EVIEWING the species of the genus Conurus for Wytsman's Genera of the species of the $C$.aeruginosus and $C$.pertinax group. Luckily $I$ have had the good fortune to receive from the Hon. W. Rothschild a large series of specimens of nearly all the known species of the group.

In the Catalogue of Birds, vol. xx., containing the Parrots, only four species of that group were recognised: $C$. cactorum, which needs no special remark, $C$. aeruginosus, $C$. ocularis, and $C$. pertinax. The want of specimens prevented me from recognising some other species. To $C$. pertinax was attribnted by ne also C. xanthogenius Bp., Consp. i. p. 1 (1850), described from a specimen said to be from Brazil. It was the good fortune of Dr. Hartert to rediscover the bird in the Island of Bonaire, fixing its specific characters (Ibis, 1903, p. 331). Also Mr. Cory (Field Mus. of Nat. Hist., Orn. i. p. 211, 1909) has received a good series of specimens collected in the Island of Bonaire by Mr. Ferry ; he also rightly notices that the golden-yellow crown will always distinguish adult birds in full plumage, while immature birds have the crown yellow with a few green feathers, or the crown green with a few yellow feathers, and, lastly, young birds have the crown entirely green withont yellow, and showing only a trace of orange yellow on the forehead. Specimens of similar descriptions are among the six birds sent me from Tring.

Of $C$. pertinax I have received four specimens, three of them from Curaçao. This species is very similar to $C$. xanthogenius, but it never has the head entirely yellow orange, although sometimes it shows yellow feathers among the green and blue ones of the top of the head. One specimen, which lived in the Zoological Society's Gardens, without exact locality, has the bill mnch stronger, with the hook very long, probably from having been kept in confinement.

Of $C$. ocularis I have examined a good series of thirteen specimens : in every one of them the green of the crown comes forward as far as the base of the bill; there is no trace of yellow frontal band. The series does not show much individual variation; on the contrary, it is very uniform. In this species the yellow patch under the eyes is sharply defined.

Of $C$. aeruginosus I have received from Tring a large series of over thirty specimens from British Guiana (Roraima, Anai), from Margarita Island, and from Venezuela (Ciudad Bolivar, Cumana, Campos Alegre, Cariaco, Altagracia, Suapure, Maipures, San Carlos (if in Veneznela), and Valencia). They show some variations ; as already remarked by Count Berlepsch and Dr. Hartert (Nov. Zool. ix. p. 107), the specimens from Ciudad Bolivar, as well as those from Suapure, have mostly more yellow about the eyes. The young birds of $C$. aeruginosus have the crown green, scarcely tinged with blue, and the yellow circle round the eyes not very prominent-nearly obsolete.

Very near to $C$. aeruginosus comes $C$. arubensis Hart., of which I have seen 


\section{$(85)$}

the type and a second specimen. Connt Berlepsch and Dr. Hartert (l.c.) have already noticed that some specimens of C.aeruginosus collected by $\mathrm{Mr}$. Cherrie in the Orinoco Region (especially from Ciudad Bolivar and Altagracia, and in Margarita Island) approach those of $C$. arubensis. I think that in some cases it will be difficult to distinguish the two forms, although the cheeks and throat of $C$.arubensis appear somewhat paler. Among the specimeus of C.aeruginosus, the more western, among those belonging to the Tring Museum, is one from Valencia.

From Antioquia, in Colombia, the Tring Museum possesses one specimen purchased from Mr. Duustall; it has been kept in confinement, and differs from all the specimens of $C$. aeruginosus in having the cheeks and throat very dark brown, the feathers of the cheeks distinctly of a scale-like appearance; besides, it as a very narrow yellow line bordering the lower eyelid. A similar specimen, but of a darker tinge on the throat and cheeks, is kept alive by Dr. Festa, of Turin. It appears to me that the latter, the Antioquian one, and probably all the Colombian ones, belong to a form distinct from the one from Venezuela and British Guiana ; the Colombian form, I think, must stand as C.chrysophrys Sw., figured by Souancé, Icon. Perr. pl. xi.

I am not acquainted with C. tortugensis Cory, Field Mus. of Nat. Hist., Orn. i. p. 220 (1909), from Tortuga Island, similar to C.aeruginosus, but with the sides of the head more orange yellow, and with the lower part of the cheeks paler, as in C. arubensis.

In conclusion, instead of the four species admitted in the Catalogue of Birds in 1891, we have now eight " : C. cactorum, from S.E. Brazil, C. xanthogenius, from Bonaire, C. pertinax, from Curaçao and Saiut Thomas, C. ocularis, from Panama, C. aeruginosus, from British Gniana and Venezuela, C. arubensis, from Aruba, C. tortugensis, from Tortuga Island, and C. chrysoplerys, from Colombia.

* In the opinion of the Editors, although they agree as to there being eight fo:ms, all of the above are subspecies of one species; and so it would be st.ange if some specimens did not show intergradations in plumage. 


\section{$2 \mathrm{BHL}$ Biodiversity Heritage Library}

Warren, William. 1912. "New Geometridae in the Tring Museum from new Guinea." Novitates zoologicae : a journal of zoology in connection with the Tring Museum 19, 68-85. https://doi.org/10.5962/bhl.part.1544.

View This Item Online: https://www.biodiversitylibrary.org/item/22249

DOI: https://doi.org/10.5962/bhl.part.1544

Permalink: https://www.biodiversitylibrary.org/partpdf/1544

\section{Holding Institution}

Natural History Museum Library, London

\section{Sponsored by}

Natural History Museum Library, London

\section{Copyright \& Reuse}

Copyright Status: Public domain. The BHL considers that this work is no longer under copyright protection.

This document was created from content at the Biodiversity Heritage Library, the world's largest open access digital library for biodiversity literature and archives. Visit BHL at https://www.biodiversitylibrary.org. 